\title{
MARXISM-LENINISM AND SOVIET-AMERICAN ECONOMIC RELATIONS SINCE STALIN
}

\author{
JerRy Pubantz*
}

\section{INTRODUCTION}

In the original Marxian scheme, governments were the product of the fundamental employer-employee relationships within the society. Supposedly in the capitalist system the primary relationship was one of exploitation and oppression imposed upon the worker by the employer through private ownership of the means of production. The economic enterprise was the institutionalization of that relationship, and according to Lenin, capitalist production was to be identified as a mainstay of imperialism. Hence, for the Soviet ideologue, post-Stalinist economic relations with capitalist business raise grave ideological obstacles. The official party line emphasizes the socialist duty to undermine the capitalist structure and denies basic doctrinal support for Soviet trade and cooperation with imperialist circles. Communist doctrine stipulates that Soviet foreign policy must bring about the world socialist revolution through concerted action against the United States. This is to be manifested in the avoidance of wide-scale cooperation with the United States and its monopolies and in economic competition leading to the "economic defeat" of the imperialist system. The "camp theory" and the doctrine of imperialism theoretically prohibit anything but the most rudimentary commerce between the Soviet and capitalist blocs. Under these theories, the continued existence of imperialism is based on the availability of new markets, resources, and investment opportunities for capitalist enterprise. If allegiance to ideology is to be preserved, the Soviet Union should not contribute to the well-being of this exploitive system by providing new areas for imperialist economic expansion, except under exigent circumstances.

How can this view be reconciled with the ever-expanding trade relations between the U.S. and the U.S.S.R.? A critical matter in the ideological framework is the manner in which the confrontation with capitalism is effectuated. The party theorists now accept that competition must be the prime characteristic of Soviet foreign economic policy, and that the United States and the Soviet Union must be the chief competitors. According to the Soviets,

Economic competition between the U.S.S.R. and the U.S.A. occupies the central position in the general progress of struggle by the socialist countries for superiority over the capitalist world in economic affairs. ${ }^{1}$

- Ph.D., Duke University, x973; Assistant Professor of Political Science, Converse College.

${ }^{1}$ A. Gromyko, Mirnoe Sosushchestvovanie-Leninskit Kurs Vneshnei Polittir Sovetskovo Soyuza I49 (I962). For a reiteration of the same view ten years later, see Kudrov, Pyatidesyatiletie SSSR; Ekonomicheshoe Sorevnovanie Dutkh Sistem, 1972 Mrrovaya Exonomika i Mezhdunarodnie OTnosheniya No. 10, at 6-7. 
It is also accepted that economic competition will occur in an atmosphere of peaceful coexistence. In pure ideological terms, the struggle between the social systems has shifted from military and political confrontation to economic confrontation. ${ }^{2}$ The current era has been characterized as primarily an economic battle between the superpowers. ${ }^{3}$

Thus, the imperatives of contemporary communist ideology impose upon the Soviet decision-maker a sense of confrontation and competition with U.S. capitalism, and the course of foreign economic relations in the post-Stalinist era is determined by the policy-maker's allegiance to this dictate. The central difficulty which he faces is to justify the U.S.-U.S.S.R. trade relations in light of the all-pervading mandate of unending competition with the capitalist West. An understanding of the accommodation which has been made requires an analysis of the Soviet interpretation of economic competition and its application to bilateral affairs with the United States.

\section{I}

\section{Foreign Economic Poutcy by Example}

According to contemporary Soviet ideology, economic competition with capitalism refers to the U.S.S.R.'s effort to surpass the United States in economic growth and affluence, as reflected in the various internationally accepted economic indices. It refers to the Soviet effort to outstrip the "citadel of imperialism" in production, labor productivity, and technological advancement. In so doing, the Soviet Union will stand as a model of what man can achieve through socialism, and its example will prod the international revolutionary movement. As L. I. Brezhnev stated to the Fifteenth Congress of Soviet Trade Unions, "[ $t]$ he force of example that socialism engenders has always played an important role in the development of the international workers' movement." 4 Economic competition is an effort to demonstrate the "Russian miracle" to the world community. Since peaceful coexistence prohibits military struggle, the world revolution must be produced through non-military means. Internal economic development is one of those means. Soviet Marxism claims that as the people of the world perceive the advantages of socialism, they will turn away from the capitalist system. This will occur sometime after the U.S.S.R. has surpassed the United States in economic growth.

Khrushchev believed that the socialist bloc would be victorious in economic competition with capitalism and that eventually the world community would be won

\footnotetext{
${ }^{2}$ Arbatov, American Imperialism and New World Realities, 23 CuRrent Digest of the Soviet Press [hereinafter cited as CDSP] No. I8, at 8 (Pravda, May 4, 1971, at 4-5). Khrushehev, On Pcaceful Coexistence, 38 Foreign Afratrs I, 4, I7 (I959).

${ }^{3}$ See N. Krrushchev, Control Figures for the Economic Development of the U.S.S.R, For I959-I965, at 79 (1960). See also Dudinsky, The World Socialist System and International Development, I969 INT'L AFF. (Moscow) No. Ix, at 58, 60 .

"Brezhnev, The Decisions of the 24th C.P.S.U. Congress Are a Militant Program of Activity for the Soviet Trade Unions, 24 CDSP No. I2, at 5 (Pravda and Izvestia, Mar. 21, 1972, at 1-3).

-Valentinov, SSSR-SShA: Razvitie Ekonomicheskovo Sorevnovanie, 1964 MirovaYa Ekonomiks I Mezhodunarodnie OtwosheniYa No. zo, at 4.
} 
over to socialism by the economic progress of the Soviet Union. ${ }^{6}$ Khrushchev's idea of peaceful competition became the party line of the C.P.S.U. in Ig6I at the Twentysecond Party Congress. ${ }^{7}$ The First Secretary's program predicted that socialist production levels would quadruple those of the capitalist world by $1980 .{ }^{8} \mathrm{Khrushchev}$ announced that the basic economic task of the U.S.S.R. was "to overtake and outstrip the most developed capitalist countries in per capita output in the briefest possible historical period." In connection with this, he maintained that "to surpass America's level of per capita output is to surpass the highest achievement of capitalism."10

As early as 1957 Khrushchev confidently predicted that the growth of the Soviet Union would outdistance the United States. He said,

In view of the fact that the pace of our industrial growth is considerably more rapid than that of the U.S.A., we can consider the task of outstripping the U.S.A. in peaceful competition in a very short time to be a perfectly real and feasible one. ${ }^{11}$

At that time the Soviet Union still trailed the United States in the production of such vital items as iron ore, pig iron, steel, cement, and wool. During his tenure Khrushchev consistently argued that domestic development was the chief form of international struggle under peaceful coexistence. This idea was first consecrated at the 'Twenty-first Party Congress in r959. Supposedly that Congress' decisions outlined a policy of economic competition with the U.S., designed to make the U.S.S.R. the supreme power. ${ }^{12}$ In ${ }^{2} 963$ at the peak of the Khrushchev campaign, the Kremlin called a Conference on Methodological Questions of Comparing Basic Economic Indices of the U.S.S.R. and the U.S.A. ${ }^{13}$ Its purpose was to find acceptable measures for Soviet and American national income, labor productivity, and per capita income. The "building of communism" required the U.S.S.R. to achieve a superior position in each of these areas.

Khrushchev proposed that the capitalists and socialists work at their own internal development, to "[l] et us give the people a chance to choose for themselves the social system which better accords with their interests."14 It was this effort at domestic economic competition that caused Western observers to perceive ideological

\footnotetext{
' See N. Khrushchev, General and Complete Disaramament Is a Guarantee of Peace and Security For All Nations 26 ( 1962 ).

${ }^{7}$ J. Triska, Soviet Communism: Programs and Rules 65 (1962).

${ }^{8}$ See Aleekseev \& Dudinsky, $K$ Okonchatel'noi Pobede v Eķonomicheskom Sorevnovanï s Kapitalizmom, 196r Mirovaya Ekonomira i Mezhdunarodnie Otwosheniya No. 9, at 25, 38.

- Khrushchev, supra note 3 , at 73 .

${ }^{10} \mathrm{Id}$. at 74 .

${ }^{11}$ Khrushchev, 40 Years of Great October Socialist Revolution, 9 CDSP No. 45, at I2 (Pravda and Izvestia, Nov. 7, 1957 , at 2-6).

${ }^{12}$ Mezhounarodnie Otnosheniya I VNeshnyaya Politika SSSR, x9I7-I960, at 52 I (F. Zuev, I. Shashin, \&. V. Niksamin eds. 1961); Andreasyan et al., Tekushchie Problemy Mirovoi Politiki, I964 Mirovaya Ekonomika I Mezhdunarodnie OtNoshenixa No. I, at 4 .

${ }^{13}$ Scientific Conference on Methodological Questions of Comparing Basic Economic Indices of the U.S.S.R. and the U.S.A., ${ }_{5}$ CDSP No. 42, at 6-12 (Vestnik statistiki, No. 6, June 1963, at 29-73).

14 Krrusharev, supra note 3 , at 164 .
} 
imperatives behind Soviet foreign economic policy. The United States was being challenged for world leadership by the Soviet economy, and the campaign for greater economic development was being exhorted to new heights by Soviet ideological desires to defeat world capitalism.

The post-Khrushchev leadership has continued the notion that peaceful coexistence demands a comparison between the economic growth rates of the Soviet Union and the United States, but has not gone to the extremes of its predecessor. Currently it asserts that socialist bloc industrial production is seventy per cent of capitalist levels and contends that during the r960's the U.S.S.R. growth rate was consistently higher than the U.S. rate. ${ }^{15}$ Soviet figures show a vast Russian improvement through 197r. Ekonomicheskaya Gazeta, for example, suggests that $197 \mathrm{I}$ demonstrated the "enormous advantage" of socialism over capitalism, because, while the United States was suffering a decline, the Soviet Union had a growth rate of 6.3 per cent. ${ }^{16}$

The campaign for peaceful competition is an effort to demonstrate advantageous contrasting features of Soviet and American domestic societies. In 1957 the following sentiment appeared in Izvestia:

Our show-windows are perhaps a little poorer, but hardly to a striking extent, and our life is universally recognized as incomparably richer, brighter and fuller, and its immediate prospects decisively outshine everything on the other side. ${ }^{17}$

The domestic aspect of U.S.-U.S.S.R. peaceful competition was highlighted by Mirovaya Ekonomika in I96r. It reported that "[e]conomic competition between the two systems is ultimately competition for the achievement of the highest labor productivity."18

This brief history indicates that, properly viewed, the Soviet pursuit of economic competition with the United States is primarily an internal Russian effort to reach the United States' production levels. ${ }^{19}$ Therefore, whether or not the effort is a result of ideological directions, its primary support does not come from the sphere of foreign policy. If domestic policy has the side effect of bringing other nations into a closer relationship with the Soviet Union, or if it brings about the diminution of American prestige, then it will achieve extra benefits for the Soviet leadership. The primary goal, however, is an improvement of the domestic situation.

II

\section{The History of Soviet-American Bilateral Relations}

The ideological imperatives of Soviet Marxism-Leninism dictate a program of restrained hostility and vigorous competition in foreign economic policy between

\footnotetext{
${ }^{15}$ Grebennikov \& Nikolayev, Economic Competition of the Two World Systems, I97I INr't Arp. (Moscow) No. 8, at I08, Iog.

${ }^{16}$ Dua Mira, Dua Itoga, r971 Eronomichesraya Gazeta No. 52, at 2.

${ }^{17}$ Gribachev, On the Other Side, 9 CDSP No. 45, at 23 (Izvestia, Nov. 6, 1957, at 6).

${ }^{18}$ Gausner, Ekonomicheskoe Sorevnovanie Duukh Sistem i Nauchno-Tekhnicheskii Progress, 196r Mirovaya Ekonomika i Mezfdunarodnie OtnosheniYa No. II, at 34.

${ }^{10}$ Aleckseev \& Dudinsky, supra note 8, at 25-39.
} 
socialist and capitalist camps. They prohibit cooperative ventures which might provide support for capitalist monopolies or might involve the Soviet Union in entangling alliances with capitalist states. In particular they prohibit close contact between the Soviet government and American business.

Immediately following the Second World War, the Kremlin leadership maintained a strict ideological line. In an attempt to rebuild the U.S.S.R., to buttress Soviet gains in Eastern Europe, and to quarantine the socialist bloc from capitalist influence, Stalin imposed an economic program predicated on attaining autarky. In his work Economic Problems of Socialism in the U.S.S.R., Stalin suggested that the most important consequence of the war was the disintegration of the world market. The emergence of two social camps following the upheaval produced "two parallel world markets . . . confronting one another."20 Stalin predicted that "it [would] soon come to pass that the socialist camp [would] no longer need capitalist imports."21 Consequently, trade between the two would come to an end, terminating Soviet economic support for capitalist enterprise.

Stalin's program of autarky produced a number of disadvantageous consequences for the Soviet Union. Not only did it end a necessary stream of Western industrial products, but it closed off a possible market for the developing Soviet productive capacity. By the middle of the I950's, the U.S.S.R. recognized the overriding advantages of inter-bloc trade, and the Twentieth Party Congress in I956 was the first step toward better economic ties with the West. The Congress sought improved commercial contacts with all the major capitalist states, particularly with the U.S. ${ }^{22}$

One of the primary tasks of the new Khrushchev regime was to open up the Stalinist economic model to world trade. To achieve this, it was necessary to break down the ideological barriers inherent in Stalin's "two market" theory. Khrushchev began by suggesting that the U.S.S.R. order heavy industrial equipment from capitalist countries such as the United States, Great Britain, and West Germany. In a I958 address to the Soviet chemical industry, he stated:

Some comrades might say that it would not be to our advantage to increase orders with the U.S.A., West Germany, Britain and other capitalist countries, that by doing so we would be supporting capitalism. These comrades are wrong.

We stand on Leninist positions and proceed from the fact that we live in a period when there are two systems-the capitalist and the socialist-and economic ties between them can develop on a mutually advantageous basis. ${ }^{23}$

Other members of the leadership also attacked Stalin's economic scheme. In March of $195^{8}$ Pravda and Izvestia reported the following incident.

\footnotetext{
${ }^{20}$ J. Stalin, Economic Problems of Socialism in the U.S.S.R. 26 (I952).

21 Id. at 27.

22 M. Airapetyan \& P. Kabanov, Leninskie Printsipy Vneshnei Politiki Sovetskovo Gosudarstra I85 (1957).

${ }^{23}$ Khrushchev, On Accelerating Development of Chemical Industry and Particularly Production of Synthetic Materials and Finished Goods for Satisfying Public Requirements and Needs of National Economy, Io CDSP No. I9, at 2I (Pravda and Izvestia, May 10, 1958, at I-4).
} 
[At a meeting of voters] A. I. Mikoyan criticized some economists who reason as follows: Since we say that the world market has split into two markets, we can no longer speak of unity of the two world markets; there is no world economy and there are no world prices. These economist comrades evidently have forgotten that unity is not identity, but there is a unity of opposites, and in the given case, of antagonistic opposites. But it is unity nonetheless. Their reasoning essentially contradicts the Leninist principle of the coexistence of the two systems. ${ }^{24}$

These attacks upon the "two market" theory had one major goal: to eliminate the ideological shackles imposed on Soviet commerce with the capitalist West. Elements of economic cooperation between ideological adversaries were allowed to find a legitimate and integral place in the process of peaceful coexistence. Cooperation in this case meant collaboration with private capitalist firms-a violation of the ideological imperatives.

In the contemporary Soviet lexicon, peaceful coexistence implies internal economic "competition" with capitalism and international economic cooperation with the major capitalist nation, the United States. ${ }^{25}$ Since 1955 Soviet trade with the United States has increased more than eight-fold. ${ }^{26}$ The extremely non-ideological nature of Soviet-U.S. commerce was noted by Khrushchev in 1958 . He told the Journal of Commerce, "[i]deological differences are in no way an obstacle to the development of mutually profitable trade between socialist and capitalist countries."27 Thus, Chairman Khrushchev did not consider the antagonistic capitalist-socialist relationship a deterrent to improved commercial ties.

Calling trade ties between the Soviet Union and the United States "a case apart"28 from the U.S.S.R.'s economic affairs with other states, the Soviets sought their expansion. In Khrushchev's words,

We [the Soviet government] consider that the successful development of trade between the U.S.S.R. and the U.S.A. on the basis of equality and mutual advantage would not only be in the interests of the Soviet and American peoples and of the strengthening of confidence in U.S.-Soviet relations, but would also contribute to the further relaxation of the international tension and would, therefore, be in the interests of all countries and peoples. ${ }^{29}$

\footnotetext{
${ }^{24}$ Meeting of Voters of Stalin Election District, Yerevan-Speech by Comrade A.I. Mikoyan, to CDSP No. Io, at Io (Pravda, Mar. I2, 1958, at 4-5; Izvestia, at 3-4).

${ }^{25}$ Osnovy Nauchnovo Kommunizma I96 (P. Fedoseev ed. 1969); Trukhanovsky, Proletarian Internationalism and Peaceful Coexistence-Foundation of the Leninist Foreign Policy, 1968 INT'L AFr. (Moscow) No. Ir, at $5 \%$.

${ }^{28}$ See Ministry of Foreign Trade of the U.S.S.R., Vneshniaja Torgovlia SSSR, Statisticheskil SBonNIK, I918-1966 (1967); Eksport SSSR Vazhneishikh Tovarov za gody 8-i Pyatiletki (1966-1970 gg.), r97I VNeshniata Torgovira No. 9, at 50-52; Import SSSR Vazhneishikh Tovarov za gody s-i Pyatiletki (1966-1970), I97I VNestiniaia Torgovlia No. 9, at 52-53; Obyem Vneshnei Torgotli SSSR $u .1971$ g." 1972 VNeshniaia Torgovlia No. 6, at 58.

${ }^{27}$ N. Khrushchev, For Victory in Peaceful Competition with Capitalism 213 (1960).

${ }^{28}$ Pinegin, Two Systems: Economic Cooperation and Competition, 1963 INT'L AfF. (Moscow) No. 3 , at 30 .

${ }^{20} \mathrm{~K}$ HRUSHCHEV, supra note 27 , at 215 .
} 
Following the Twentieth Party Congress the Kremlin made a strong effort to enlarge the trade volume between the superpowers. In particular, Russian imports of American goods rose rapidly after $1954^{30}$ Table I gives the relevant quantities of heavy machinery imported from the United States, according to Soviet figures. From the ideological viewpoint, the importation of materials in the heavy industrial sector raised the greatest difficulty. It was in this particular area that Stalin hoped to make the socialist camp self-sufficient. The production of heavy industry materials is supposed to be one of the prime supports of the capitalist system. Consequently, Soviet purchases of these commodities amount to a subsidization of the imperialist structure.

TABLE $\mathrm{I}^{31}$

Soviet Machinery and Equipment Imports from the United States

\begin{tabular}{c|c|c|c|c|c}
\hline Year & $\begin{array}{c}\text { Machinery and } \\
\text { Equipment Imports } \\
\text { (in millions of rubles) }\end{array}$ & Year & $\begin{array}{c}\text { Machinery and } \\
\text { Equipment Imports } \\
\text { (in millions of rubles) }\end{array}$ & Year & $\begin{array}{c}\text { Machinery and } \\
\text { Equipment Imports } \\
\text { (in millions of rubles) }\end{array}$ \\
\hline 1954 & 1 & 1959 & 5,905 & 1964 & 3,630 \\
1955 & 27 & 1960 & 24,953 & 1965 & 4,974 \\
1956 & 2,289 & 1961 & 14,174 & 1966 & 6,723 \\
\hline
\end{tabular}

The other primary type of Soviet-American trade under Khrushchev was agricultural. In particular, I964 witnessed a huge grain purchase by the U.S.S.R. The Kremlin bought nearly two million tons of grain at a cost of I09 million rubles. It also contracted for 55,000 tons of rice. ${ }^{32}$ However, agricultural transactions were unique occurrences, not meant to reflect any general policy decision. They constituted a Soviet effort to fill a chronic domestic need for grain. Thus, these purchases did not relate to the ideological issue per se, and were, perhaps, further examples of the priority of Soviet national interest over ideology. The fulfillment of internal demand was visualized as a stronger imperative than those limiting commerce with the "citadel of imperialism."

Khrushchev's efforts indicate that the obstacles to increased Soviet-American trade were not ideological in origin. Once Stalin's concept of two world markets was eliminated, the path was open to improved economic relations with the United States. Howvever, during Khrushchev's tenure, despite the examples cited above, there was no mammoth increase in the U.S.-U.S.S.R. trade volume. The reason for the disparity between Soviet desires and actual performance was not ideology but rather American restrictions on trade with communist countries. The United States government prohibited commercial transactions with the Soviet Union on most

\footnotetext{
${ }^{30}$ Soviet imports of American products began to exceed exports in 1960 . It should be remembered, however, that Soviet exports to the United States were greatly affected by heavy American import restrictions on Russian goods.

${ }^{81}$ Geograficheskoe Raspredelenie Importa Nekotorykh Tovarov Po Stranam, VNeshniala Torgovlia SSSR, StatTSTICHeskil SBORNIK, I918-1966, at 142-43 (I967).

${ }^{32}$ Eksport $i$ Import SSSR Po Stranam $i$ Tovaram, VNeshniala Torgovlia SSSR, StatistichesriI SвORNIK, I9I8-I966, at 228-29 (rg67).
} 
products. In particular, stringent American restrictions existed on the importation of Soviet merchandise. This freeze on the entry of Soviet exports produced a Soviet deficit in U.S.S.R.-U.S. trade beginning in 1960 .

The continuing trade deficit has been one of the major factors motivating the postKhrushchev desire for trade with the United States. In $197 \mathrm{r}$ the Soviet trade deficit exceeded 74 million rubles. ${ }^{33}$ I97I was also first year of the U.S.S.R.'s Ninth FiveYear Plan which contained a general commitment to expand exports. ${ }^{34}$ The increase in domestic production in recent years has created a need for the development of new markets. From the Soviet point of view, the optimal markets would be the advanced capitalist states, in particular the United States. ${ }^{35}$

Beyond trade, the current leadership has sought American investment in the Soviet economy. According to one Western writer, "The Soviet economy isn't producing either the technology or the capital investment funds needed to move the U.S.S.R. into superpower status." ${ }^{\text {"36 }}$ Therefore, the Kremlin has argued that the scientific-technical revolution makes possible and necessary U.S.Soviet cooperation in the development of the Russian economic sector. According to the Soviets, there is presently a need to select the most rational forms of cooperation, such as the joint development of Soviet natural resources. ${ }^{37}$ In this endeavor, "American corporations would be suitable and interested parties."38 American banks also could participate in the process. ${ }^{39}$

In G. Arbatov's view the Cold War of the I960's was the chief obstacle to extensive cooperation. ${ }^{40}$ With the easing of political tensions in recent years, economic partnership became feasible, not only in the utilization of natural resources but also in the construction of Soviet industrial enterprises and in technical research. ${ }^{11}$ The conclusion of the Cold War ushered in a Soviet effort to import American technology and management sciences; and the current period has witnessed increasing

\footnotetext{
${ }^{33}$ Obyem Vneshnei Torgovli SSSR v 1971 g., 1972 VNEShNind Torgovira No. 6, at 58.

${ }^{3 *}$ Pichugin, Novaya Pyatiletka i Mezhdunarodnoe Ekonomicheskoe Sotrudnichestvo, 1972 MrzHDUNAROdNAYA ZHZZN' No. I, at Io-II.

${ }^{35}$ Shershnev, Soviet-American Trade: Problems and Possibilities, 24 CDSP No. 19, at I, 6 (1972 S.Sh.A.: Ekonomirs, Politirs, Ideologis No. 4, at 3-r4). The desirability of trade with the industrialized West has led to increasing commerce with capitalist enterprises since 1960 at the expense of Soviet trade with other socialist states. See also Commitree for Economic Developinent, A New Trade Policy Toward Communist Countries 14 (1972).

${ }^{80}$ Keatley, Let's Make a Deal, Wall Street Journal, May r8, 1972, at I, col. I.

${ }^{37}$ According to the Department of Commerce, the Soviet need for U.S. credits is the greatest in the area of raw materials development. U.S. Dep'T of Comarerce, U.S.-Soviet Commercinz Relationships IN A NEW ERA 20 (1972).

${ }^{38} \mathrm{Id}$. at 5 .

${ }^{30}$ Matveyev, Prospects for Trade Between the U.S.S.R. and the U.S.A., 24 CDSP No. 3, at 9 (Izvestia, Jan. 22, 1972, at 4).

${ }^{10}$ See Arbatov, Perspektivy Razryadki Sovetsko-Amerikanskikh Otnoshenii, 1972 S.S.H.A.: Exonomika, Politike, Ideologrya No. 2, at 29. See also Svetlov, SSSR i SShA-Vozmozhnosti i Deistvitel 'nost', 1972 Mezhdunarodnaya ZetzN' No. I, at 2I, 23.

1 Kosygin, On the State Five-Year Plan for the Development of the U.S.S.R. National Economy in 1972, 23 CDSP No. 47, at I2, 24 (Pravda, Nov. 25, I971, at I-4; Izvestia, at 2-4).
} 
Soviet imports of complex American machinery and technological advancements in vital areas of the U.S.S.R.'s economy. ${ }^{42}$

In 1969 the volume of Soviet trade with the United States was still less than that between the U.S.S.R. and Finland. ${ }^{43}$ Since that time, however, there has been an expansion of U.S.-U.S.S.R. commerce. In particular, the Kremlin has sought American machinery, chemicals, and synthetic fibers. As payment the Soviet Union has exported raw materials and mineral fuels. ${ }^{44}$ Also, beginning in Ig69 the Kremlin made a positive effort to attract American investment. During 1970 the leadership commenced discussions with the Ford Motor Company about the possibilities of U.S. capital being employed in the Soviet Union. In the case of Ford, the Soviets hoped to negotiate the construction of a truck factory. While the subsequent year did not produce an agreement with Ford, it did present some successes on other fronts. In particular, on November 30, I97I, the Kremlin signed contracts valued at 125 million dollars with a number of U.S. firms. ${ }^{45}$ The agreement between the Soviet Union and the Satra Corporation, which represented all the American firms, created more than a sixty per cent increase in Soviet-U.S. trade levels. The U.S.S.R. purchased 65 million dollars in equipment, much of it for mining and petroleum production. In return, the Soviets sold the firms 60 million dollars worth of non-ferrous metals-copper, zinc, and lead. ${ }^{46}$

The post-Khrushchev elite has sought closer economic cooperation with U.S. capitalism and has ignored ideological imperatives. It has done this in order to correct its balance of payments position with the United States. Further, it has sought the advantages of U.S. technology and investment capital for its own internal economic development. Finally, the current U.S.S.R. leadership looks upon stable economic ties and close cooperation as essential elements in the process of détente and as useful instruments for the resolution of various international difficulties. ${ }^{\mathbf{4 7}}$ The easing of tensions and the improvement of economic relations are seen as mutually-assisting factors. On the one hand, as political controversy subsides, cooperation becomes less objectionable to the protagonists and new contacts develop. A case in point was the opening of new air routes needed for commerce between Moscow and New York. ${ }^{48}$ The relaxation in Soviet-American political relations encouraged these contacts. On the other hand, the settlement of economic issues can contribute to the settlement of political problems. The fishing agreements signed

\footnotetext{
${ }^{12}$ Sec, e.g., Eksport $i$ Import SSSR po Stranam i Tovaram, VNeshiniaIA Torgovila Soyuza SSSR za Ig69 GOD., STATISTICHESKII OBZOR 290 (I970).

${ }^{3}$ See Istoriya VNeshnei Politika SSSR, Chast Vtoraya, 1945-I970 gG. 454 (B. Ponomatev, A. Gromyko, \& V. Khostov eds. I97I).

"U.S. DeP'T OF CoMMerce, supra note 37, Annex B, at 78-79.

${ }^{6}$ On Soviet-American Trade Relations, 23 CDSP No. 48, at 5 (Pravda, Dec. I, I97I, at 5).

${ }^{40}$ Shabad, U.S.-Soviet Pacts Signed, N.Y. Times, Dec. I, I97I, at I, col. 7 .

${ }^{47}$ Matveyev, supra note 39 , at 9.

${ }^{48}$ Civil Air Transport Agreement with the Union of Soviet Socialist Republics, Nov. 4, 1966, [1966] 2 U.S.T. Ig09, T.I.A.S. No. 6135,675 U.N.T.S. 4 .
} 
by the United States and the U.S.S.R. in 1968 , and extended in $1970,{ }^{40}$ were illustrations. Soviet fishing practices off the East Coast of the United States not only injured the internal economic conditions of the United States but also strained political relations between the two countries. The Soviet operations threatened the supply of fish and served as a cover for espionage activities. The amicable settlement of the issue resolved both economic and political difficulties.

To summarize, the Soviet Union since 1964 has sought cooperative economic relations with the United States for three reasons: (I) to correct its balance of payments situation with Washington, (2) to import American technology and investment capital for the development of the Soviet economy, and (3) to strengthen and expand the process of détente begun in the period of peaceful coexistence. None of these motives has ideological origins. Each outlines a course of action contrary to the imperatives of the current ideology. As indicated earlier, orthodox Marxism-Leninism espouses a course of non-cooperation and economic restraint in Soviet-American relations. Indeed, following the Second World War the Stalinist program of autarky coincided with these doctrinal demands. Only after Stalin's death and the change in requirements of Soviet national interest did the Kremlin leadership move toward cooperation. Peaceful coexistence in U.S.U.S.S.R. bilateral economic relations has meant the rejection of ideology in the policy process. In particular, as Cold War tensions have diminished and Soviet internal economic needs have expanded, the Brezhnev-Kosygin-Podgorny regime has ignored the postulated ideological restraints on contacts with capitalist circles and has moved to meet the requirements of the Soviet state.

\section{III}

\section{The Summit and the Future of Soviet-American Economic Relations}

A major landmark in the movement toward bilateral cooperation was the 1972 Moscow summit. In the months preceding President Nixon's arrival in the U.S.S.R. the Soviet press indicated that economic trade and cooperation were prime topics for discussion. According to the Kremlin, the only obstacles to improved commercial relations were the arbitrary discriminatory barriers maintained by the U.S. against Soviet goods. If reciprocity and economic equality could be recognized in the summit agreements, then both states could expand trade..$^{50}$

In the negotiations both sides sought specific goals. The United States wanted any trade agreement to be comprehensive and include a resolution of the U.S.S.R.'s World War II lend-lease debt and provisions to assist and protect American business operating in Russia. The Soviet Union sought above all else a grant of most-favored-

\footnotetext{
${ }^{49}$ Agreement with the Union of Soviet Socialist Republics on Certain Fishery Problems on the High Seas in the Western Areas of the Middle Atlantic Ocean, Dec. Ir, 1970, [1970] 3 U.S.T. 2664, T.I.A.S. No. 7009.

${ }^{80}$ Shershnev, supra note 35, at 4; Klochek \& Pekshev, The U.S.S.R.'s Foreign Trade in r97I, 24 CDSP No. 20, at I, 2 (I972 Ekonomicheskaya Gazeta No. 17, at 20-21); Svetlov, supra note 40, at 27; Arbatov, stupra note 40 , at 28.
} 
nation status which would end the twenty-two-year-old American discrimination against the U.S.S.R. The Kremlin also desired long-term credits for its purchases. The achievement of these goals would have been understood in the Kremlin as U.S. recognition of mutual trading equality. ${ }^{51}$

While significant progress toward a trade accord was made, the summit talks did not produce a final document. The only formal result was the creation of a U.S.Soviet Joint Commercial Commission to continue the discussions and make proposals. Beyond this, the two countries' leaders made economic cooperation an element of the mutually-recognized concept of peaceful coexistence. The seventh point of the "Basic Principles" signed in Moscow stated,

The U.S.A. and U.S.S.R. regard commercial and economic ties as an important and necessary element in the strengthening of their bilateral relations and thus will actively promote the growth of such ties. They will facilitate cooperation between the relevant organizations and enterprises of the two countries and the conclusion of appropriate agreements and contracts, including long-term ones. ${ }^{2}$

While the discussions did not result in a comprehensive accord at the time, it was clear that the Soviets seriously sought economic ties. Shortly after the summit, the U.S.S.R. negotiated comprehensive contracts with a number of U.S. firms. The most important of these was an accord with the Occidental Petroleum Corporation signed on July I4, I972. Under a five-year agreement the U.S.S.R. Council of Ministers obtained Occidental's assistance in the extraction and processing of oil and gas, in the production of agricultural fertilizers and chemicals, in the treatment of metals and plating, in the design and construction of hotels, and in the utilization of solid wastes. ${ }^{53}$ Observers indicated that the trade package could be worth 3 billion dollars with Occidental receiving compensation in the form of gas, oil, and other raw materials (nickel, chromium, etc.). In particular, the American company would assist the Kremlin in the development of the Tyumen gas fields in Siberia. ${ }^{54}$ This venture could also include Japanese investment. ${ }^{55} \mathrm{In}$ other transactions the U.S.S.R. contracted with a number of firms to assist in the development of the Soviet Union's new Kama River Tractor Plant. Moscow granted Gulf-Western a contract to supply a production line for the complex. ${ }^{56}$ The Thermo Electron Corporation received an

\footnotetext{
${ }^{61}$ Baza Dlya Razvitiya Sovetsko-Amerikanskikh Otnoshenii, 1972 S.SH.A.: Exonomika, PoLITnkA, IDEOLOGIYA No. 7, at 4 .

62 Basic Principles of Relations Between the United States of America and the Union of Soviet Socialist Republics, Signed in Moscow on May 29, r972, 66 Dep'T State Bull. 898, 899 (x972).

${ }^{63}$ Cooperation Develops, 24 CDSP No. 24, at I9 (Pravda, July 20, 1972, at 4). Wesson, The SovietAmerican Arms Limitation Agreement, 3I Russinn Rev. 334, 342 (I972). The Occidental-Soviet agreement on metal finishing equipment was only completed in December, 1972. See Wall Street Journal, Dec. 15,1972 , at 6 , col. 2.

" Known as the North Star Project, the extraction of gas from the Tyumen region will also include the participation of the Texas Eastern Transmission Corporation, Tenneco, and Brown and Root. These U.S. companies will be involved in transporting the gas to Murmansk, liquifying it, and shipping it to the United States. H. Humphrey \& H. Reuss, Jornt Economac Comm., 93D Cong., IST Sess., Observations on East-WEst Economic Relations: U.S.S.R. and Poland 4 (Comm. Print I973).

Et Wall Street Journal, July I9, I972, at 2, col. 2.

${ }^{50}$ Wall Street Journal, June 5 , I972, at 5 , col. 3 .
} 
order for twenty-two industrial furnaces. ${ }^{57}$ In all, the Kremlin contemplated $x$ billion dollars in U.S. purchases for industry.

In order to finance these new economic projects the Soviets have sought two types of Western credits: short-term deferred payment credits which would be related to specific purchases, and long-term "project loans" for internal investment purposes. To achieve both forms of financing during 1972, the Soviet Union commenced discussions with several U.S. and West European banks. To establish a credit rating, the International Bank for Economic Cooperation, the Moscow-based banking institution for the socialist economic bloc (CEMA), borrowed I40 million dollars during the first half of 1972 . Finally, in November of that year the Kremlin permitted the Chase Manhattan Bank to open a Moscow branch. ${ }^{58}$ These measures cleared the way for steady progress toward closer U.S.Soviet commercial ties. On October I8, 1972, a comprehensive economic agreement was reached between the United States and the Soviet Union. ${ }^{59}$ The accord called for a "new era of commercial friendship," and it essentially fulfilled both sides' goals discussed during the summit talks. Article I granted the U.S.S.R. the most-favored-nation status it sought and established reciprocity and equality as the foundation of the accord. The threeyear agreement called for tripling of trade to the level of $\mathrm{r} .5$ billion dollars. The U.S. would export machine tools, heavy industry equipment, consumer goods, and grain products. In return the United States would receive Soviet natural resources. Significantly, the U.S.S.R. would have a right to long-term export-import credits, and the United States would receive repayment of the long-standing lend-lease debt in the amount of 722 million dollars. It would also continue, for the time being, its favorable trade balance at a ratio of three to one. ${ }^{60}$

In spite of the October agreement, however, and in spite of individual cases of Soviet-American corporation contracts, the prospects for Soviet-U.S. economic relations remains somewhat restricted. While the potential exists for trade to increase rapidly, various obstacles limit the possibilities. First, in order to obtain complex and sophisticated American goods, the Soviet Union will have to offer in return items which U.S. enterprises demand. Except for foreign exchange and natural resources, the Soviet economy has little that is attractive to the American buyer. Second, "Soviet-United States commercial relations which have begun to expand rapidly will level off again or be set back unless large-scale joint ventures in gas, oil and other raw materials are worked out." ${ }^{\text {"61 }}$ U.S. corporations will not enter these cooperative projects unless they have on-site inspection rights and they perceive their natural

\footnotetext{
${ }^{57}$ Wall Street Journal, Aug. 2, x972, at 6, col. 4 .

${ }^{58}$ Stabler, Communists Learn How to Borrow Dollars-And They Want More, Wall Strect Journal, June 20, 1972, at I, col. 6; Wall Street Journal, Nov. 15, 1972, at 10, col. 3.

${ }^{89}$ Agreement with the Union of Soviet Socialist Republics Regarding Trade, 67 Dep'T State BuzL. 595 (1972). For an American discussion of the accord's importance, see Armstrong, A New Era for East-West Trade, 67 Dep't State BuII. 721 (I972).

${ }^{60}$ News Conference of Secretary Rogers and Secretary Peterson, 67 Dep't State Buld. 58r, 583-88 (1972).

${ }^{61}$ H. Humpherey \& H. Reuss, Joint Economic Comm., 93D Cong., Ist Sess., supra note 54, at 9.
} 
resource development investments as good growth prospects. ${ }^{62}$ Since this amounts to an inflow of finance capital, the Kremlin must be concerned about strengthening the imperialist system through these projects.

There is also a question as to the potential size of U.S.Soviet natural resource trade. According to the U.S. Department of Commerce, "It will be a number of years before the dollar volume of our Soviet trade amounts even to a few per cent of our total consumption, even in those raw material and energy areas where we expect our heaviest import concentrations. ${ }^{363}$ Much will depend on possible future supplies from the Middle East and newly discovered Alaskan deposits. If U.S. concerns are able to fill their requirements more cheaply and efficiently from these regions, then they will not have to rely on the U.S.S.R.'s reserves. Furthermore, Soviet quantities are not unlimited. With increasing socialist bloc needs, Japanese requirements, and contracted supplies to Europe by way of the Siberian-Bavarian pipeline, the prospects for fulfilling the American requirements in the near future seem slim. Finally, until Soviet currency is fully convertible, the price structures and economies of the two states will restrict the limits of mutually advantageous trade. Inevitable internal economic disruptions will result which each government will have to alleviate. Until Soviet products are allowed to find their own price on the world market, U.S. firms will be leary of contractual arrangements.

\section{ConcLusion}

While future prospects for trade between the Soviet Union and the United States remain clouded, it is important to note that the present obstacles are non-ideological in nature. The primary difficulties are American reservations and Soviet noncapability to deliver goods. Direct economic relations between the leaders of socialism and capitalism exhibit little evidence of Soviet ideological influence. The growing Soviet need for American technology and investment, and the desire for a consistent policy of détente have overridden the ideological imperatives which prohibit wide-scale cooperation with imperialist monopolies and demand resolute Soviet action to bring about the world socialist revolution. In their place, peaceful coexistence has imposed a program aimed at filling the Soviet state's economic needs based on the principles of equality and reciprocity regardless of Marxist-Leninist prescriptions.

\footnotetext{
${ }^{03}$ U.S. DEP'T of CoMmerce, supra note 37 , at 40 .

${ }^{03}$ Id. at 4 .
} 